\title{
RANCANG BANGUN DAN UJI KINERJA MESIN PEMARUT DAN PEMERAS SANTAN KELAPA
}

\author{
Romi Djafar ${ }^{1)}$ Agus Susanto Ginting ${ }^{2)}$ \\ ${ }^{1,2)}$ Tim Pengajar pada Program Studi Mesin dan Peralatan Pertanian, Politeknik Gorontalo
}

\begin{abstract}
ABSTRAK
Porivinsi Gorontalo merupakan salah satu sentra penghasil kelapa berdasarakan data BPS tahun 2016, gorontalo menghasilkan 54,6 ribu ton kelapa. Secara umum proses ekstraksi daging kelapa menjadi santan dilakukan dengan proses pemerasan secara manual. Selain dilakukan secara manual proses ektraksi juga dapat dilakukan dengan menggunakan mesin. Beberapa industri rumah tangga sudah menggunakan mesin pemeras santan dengan sistem batch dengan kapasitas yang relatif kecil. Proses pemerasan merupakan proses yang terpisah dengan pemarutan sehingga membutuhkan waktu yang lebih lama dalam ektraksi daging kelapa menjadi santan. Pada penelitian ini akan difokuskan bagaimana cara untuk memaraut kelapa yang selanjutnya diperas untuk menghasilkan santan kelapa secara berkenlajutan (Continu)
\end{abstract}

Kata Kunci : kelapa, ekstraksi, santan

\section{ABSTRACT}

Gorontalo Province is one of producer of coconut. Based on Center of Statistic Berau (BPS) 2016, Gorontalo produces 54.6 thousand tons of coconut. In general, the process of extracting coconut meat into coconut milk is done by manual squeeze. Besides being done manually the extraction process can also be done using machine. Some home industries have used coconut milk squeezer machines with batch systems with relatively small capacity. The process of extraktion is separate process with solubility so that it takes longer to extract coconut meat into coconut milk. This research will be focused on grated the coconut then continu to squeezed to produce coconut milk in once process

Key Words : coconut, extraktion, coconut milk 


\section{PENDAHULUAN}

Porivinsi Gorontalo merupakan salah satu sentra penghasil kelapa berdasarakan data BPS tahun 2016, gorontalo menghasilkan 54,6 ribu ton kelapa. Kelapa akan digunakan untuk berbagai keperluan diantaranya untuk kebutuhan rumah tangga, kopra yang selanjutnya akan diekstrak menjadi minyak kelapa, dan santan yang selanjutnya akan diolah menjadi minyak kelapa murni (VCO).

Santan kelapa merupakan salah satu komponen penting dalam menciptakan rasa makanan yang lezat disamping itu santan kelapa merupakan sumber dari minyak nabati yang baik. Asam palmitat dan asam stearat yang kaya pada santan kelapa banyak juga digunakan untuk kebutuhan industri kosmetik dan farmasi. Secara umum proses ekstraksi daging kelapa menjadi santan dilakukan dengan proses pemerasan secara manual. Tahapan proses ini diawali dengan pemisahan daging kelapa dari tempurungnya dengan cara pemarutan. Proses pemarutan ini dapat dilakukan secara manual dengan cara menggesekkan permukaan daging buah kepermukaan besi bergerigi tajam atau dapat juga dilakukan dengan mesin sederhana dengan memutar komponen pemarut dengan tenaga motor listrik atau motor bensin. Tahapan kedua adalah pencampuran kelapa yang sudah diparut dengan air untuk memudahkan santan terlapas dari daging kelapa.

Tahapan ketiga adalah proses pemerasan yang dilakukan secara manual dengan cara meremas parutan kelapa yang bercampur dengan air secara berulang. Proses ini juga dapat dilakukan dengan memasukkan sejumlah parutan kelapa kedalam wadah kain berpori kecil dan selanjutnya diperas menggunakan tangan atau dengan bantuan kayu atau sejenisnya. Tahapan terakhir adalah proses pengendapan santan kelapa dengan air. Proses ini terjadi berdasarakan perbedaan berat jenis dimana santan kelapa mempunyai berat jenis yang lebis besar akan terpisah dari air yang mempunyai berat jenis yang lebih kecil.

Proses ekstraksi seperti dijelaskan diatas selain dilakukan secara manual juga dapat dilakukan dengan menggunakan mesin. Beberapa industri rumah tangga sudah menggunakan mesin pemeras santan dengan sistem batch dengan kapasitas yang relatif kecil. Proses ini juga merupakan proses yang terpisah dengan pemarutan sehingga membutuhkan waktu yang lebih lama dalam ektraksi daging kelapa menjadi santan.
Pada penelitian ini akan difokuskan bagaimana cara untuk memaraut kelapa yang selanjutnya diperas untuk menghasilkan santan kelapa secara berkenlajutan (Continu). Mesin pemarut dan pemeras santan kelapa tersebut terdiri dari rancangan fungsional dan rancangan struktural dalam mendukung kinerjanya. Racangan struktural terdiri dari hoper, pemarut daging kelapa, rangka mesin, pemeras, sumber tenaga penggerak, pemarutan kepala selanjutnya keluar melalui saluran pengeluaran yang sudah berpisah ampas kelapa. Rancangan fungsional merupakan penjabaran dari fungsi-fungsi tiap komponen mesin. Hoper berfungsi sebagai saluran pemasukkan daging kelapa yang sudah dipisahkan dari dari tempurungnya. Pemarut berfungsi untuk mencacah daging kelapa menjadi ukuran yang lebih kecil. Pemeras berfungsi untuk mengekstrak parutan kelapa untuk menghasilkan santan. Rangka mesin berfungsi untuk menopang konstruksi mesin secara keseluruhan. Sumber tenaga berupa motor bensin berfungsi untuk memutar pemarut dan pemeras. Gear box berfungsi untuk mereduksi putaran yang digunakan untuk pemeras dan saluran pengeluaran untuk memisahkan antara santan dan ampas kelapa.

Struktur dan fungsi dari mesin yang akan dirancang diharapakan mampu membuat proses ekstraksi daging kelapa menjadi santan lebih cepat dan lebih bersih.

\section{METODE PENELITIAN}

\section{Alat dan Bahan}

Bahan yang digunakan terdiri atas dua kelompok. Pertama, bahan yang digunakan untuk konstruksi yang terdiri dari besi siku ukuran $4 \times 4$ $\mathrm{cm}$ tebal $2 \mathrm{~mm}$ yang digunakan sebagai bahan untuk konstruksi rangka mesin. Stainlees steel untuk konstruksi hoper, pemarut dan pemeras. Bahan pendukung untuk konstruksi terdiri dari batu gerinda potong, batu gerinda halus, pulley, v-belt, circular saw, elektroda, gear box, motor bensin dan baut. Kedua, bahan yang digunakan untuk penggujian berupa kelapa yang sudah terkupas dari tempurungnya dan bahan bakar bensin yang digunakan sebagai sumber tenaga penggerak motor. Mesin yang digunakan dalam membangun mesin ini adalah mesin las listrik dan mesin las karbit untuk membentuk kerangka dan hoper. Konstruksi bagian pemeras menggunakan mesin bubut, mesin bor dan mesin milling. Proses finishing menggunkan mesin gerinda halus dan kompresor untuk pengecatan. 


\section{Rancangan Fungsional}

Komponen dari mesin yang akan dirancanga terdiri dari kerangka mesin, hoper, pemarut dan pemeras. Kerangka berfungsi sebagai penopang dan tempat melekat komponen secara keseluruhan. Hoper terdiri dari dua bagian : pertama, hoper sebagai saluran pengumpan untuk proses pemarutan, kedua, sebagai saluran pengumpan untuk proses pemerasan. Pemarut berfungsi untuk mengecilkan ukuran daging kelapa untuk memperkecil luas permukaan daging sehingga mepermudah pemerasan. Pemeras berfungsi untuk mengekstrak daging sehingga diperoleh santan dan ampasnya. Gambar 1 berikut menunjukkan bagian-bagian tersebut.

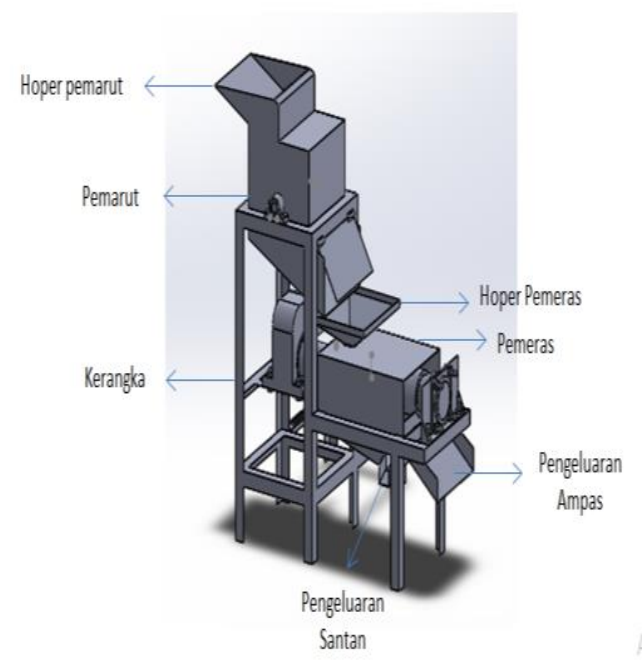

Gambar 1 konstruksi Mesin Dan Bagian Bagiannya.

\section{Rancangan Struktural}

\section{a. Kerangka Mesin}

Kerangka mesin terbuat dari besi siku dengan ukuran $4 \mathrm{~cm}$ x $4 \mathrm{~cm}$ dengan ketebalan $2 \mathrm{~mm}$. Dimensi kerangka mempunyai panjang $65 \mathrm{~cm}$, lebar $35 \mathrm{~cm}$ dan tinggi $80 \mathrm{~cm}$. Kerangka disusun secara bertingkat dimana pada bagian tas merupakan dudukan sistem pemarutan dan undakan bawah merupakan dudukan untuk sistem pemerasan. Panjang penopang pemeras sepanjang $35 \mathrm{~cm}$

\section{b. Pemarut}

Pemarut mempunyai panjang $19 \mathrm{~cm}$, bahan pemarut ini terbuat dari stenless steel. Diamater komponen pemarut sebesar $10 \mathrm{~cm}$. Kedua ujung pemarut dilengkapi poros pemutar dari besi dengan diamater $2,5 \mathrm{~cm}$. Poros pemarut dirancang bergerigi sepanjang keliling tabung

\section{c. Komponen Pemeras}

Keseluruhan komponen pemeras terbuat dari stenless steel yang terdiri dari ulir pemeras, selubung ulir, dan penutup komponen pemeras. Ulir pemeras mempunyai panjang $35 \mathrm{~cm}$, komponen ini terdiri dari dua bagian yakni ulir sebagai pembawa parutan kelapa sepanjang $25 \mathrm{~cm}$ dan besi pejal berbentuk menyerupai kerucut sebagai pemeras sepanjang $10 \mathrm{~cm}$. Poros ulir pemeras terbuat dari besi poros berdiamater $10 \mathrm{~cm}$. Ulir pemeras tersebut akan dimasukkan kedalam selubung ulir yang berlubang-lubang sebagai pengeluaran santan. Dimensi selubung ulir ini mempunyai panjang 35 $\mathrm{cm}$ dan diamater $12,5 \mathrm{~cm}$. Ulir dan selubungnya akan dilangkapai penutup untuk menjaga kebersihan proses.

\section{d. Parameter Pengujian}

Terdapat dua pengujian kapasitas yang dilakukan terhadap performa mesin. Pertama merupakan pengujian terhadap kapasitas pemarutan. Proses ini menghitung banyaknya daging kelapa terparut $(\mathrm{kg})$ tiap satuan waktu (jam) yang dibutuhkan. Persamaan 1 digunakan untuk menghitung kapasitas pemarutan (kg/jam) sebagai berikut.

$$
\text { Kapasitas pemarutan }\left(\frac{\mathrm{kg}}{\mathrm{jam}}\right)=\frac{\text { Berat daging kelapo }(\mathrm{kg})}{\text { waktu pemarutan (jam) }}
$$

Berikutnya dilakukan perhitungan kapasitas pemerasan. Proses ini untuk menghitung banyaknya kelapa yang diperas dalam satuan waktu. Kapasitas pemerasan dihitung berdasarkan persamaan 2 sebagai berikut.

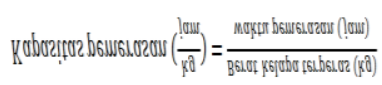

Disamping itu juga dilakukan perhitungan rendemen pemerasan. Perhitungan ini dilakukan untuk mengetahui persentase cairan santan yang diperoleh dari kelapa parut berdasarkan basis massa $(\mathrm{kg})$. Persamaan 3 berikut digunakan untuk menghitung besarnya rendemen tersebut.

$$
\text { Rendemen santan }(\%)=\frac{\text { Berat kelapa parut }(\mathrm{kg} g}{\text { Berat santan }(\mathrm{kg})} \times 100 \%
$$

\section{HASIL DAN PEMBAHASAN}

\section{Kinerja Fungsional dan Strktural Mesin}

Secara umum mesin pemarut dan pemeras santan hasil rancangan mampu berkerja dengan baik. Putaran mesin yang ditransmisikan menggunakan sistem puli dan v-belt yang bersumber dari motor bensin 4 langkah dengan daya 5.5 Hp. Putaran mempunyai dua jalur : pertama ke komponen pemarut dan kedua ke komponen pemeras. Putaran mesin ke komponen 
pemeras kemudian direduksi dengan menggunakan gear box dengan perbandingan putaran 1:50 untuk mendapatkan putaran ulir pemeras sebesar $33 \mathrm{rpm}$. Pada komponen pemarut diperoleh kecepatan putar komponen sebesar $1218 \mathrm{rpm}$.

Struktur kerangka mesin dari besi siku dengan ukuran $4 \mathrm{~cm}$ x $4 \mathrm{~cm}$ sebagai tempat melekatnya komponen mesin mampu berfungsi menahan bobot semua komponen. Kerangka mesin dalam kondisi stabil menopang beban kerja baik pada saat pemarutan dan pada saat pemerasan santan kelapa. Poses pemarutan kelapa dan pemerasan santan dimulai dengan memasukkan daging kelapa melalui saluran pemasukkan (hopper) yang dilanjutkan keruang pemarutan. Fungsi komponen pemarut mampu bekerja dengan baik dalam mengecilkan ukuran daging kelapa. Parutan kelapa kemudian akan keluar dari saluran pengeluaran (outlet). Kendala yang dihadapi pada proses ini adalah parutan kelapa tidak lancar mengalir hal ini kemungkinan disebabkan oleh sudut curah (angle of repose) untuk saluran pengeluaran yang belum tepat dengan sudut curah parutan kelapa.

Proses pemerasan merupakan proses lanjutan setelah pemarutan. Pada proses ini parutan kelapa akan masuk keruang pemarutan melalui hopper pemeras. Mekanisme pemerasan adalah dengan sistem pemadatan melalui ulir pemeras yang berbentuk tirus. Pada proses ini akan dihasilkan santan murni hasil pemerasan parutan kelapa. Hasil pemerasan ini terdiri dari dua jenis yakni santan kelapa yang akan keluar dari kisi-kisi pemerasan dan dilanjutkan dengan ke saluran pengeluaran santan dan ampas kelapa yang akan diteruskan ke seluran pengeluaran ampas. Kendala yang dihadapi pada proses ini adalah masih tersisanya ampas kelapa pada ruang pemeras.

\section{e. Kapasitas Pemarutan}

Pengujian pemarutan kelapa dilakukan dengan berat sampel 1000 gram yang dilakukan dengan 3 kali ulangan. Data yang diperoleh kemudian dihitung dengan persamaan satu (1). Hasil pengujian menunjukkan kapasitas pemarutan sebesar 25,52 kg/jam. Nilai ini lebih tinggi dari kapasitas pemarutan yang dilakukan secara manual sebesar 7,2 kg/jam

\section{f. Kapasitas pemerasan}

Pemerasan daging kelapa yang sudah diparut menggunakan sampel sebanyak 1000 gram. Perhitungan data dihitung dengan persamaan dua (2). Hasil pengujian menunjukkan kapasitas pemerasan sebesar $5 \mathrm{~kg} / \mathrm{jam}$. Nilai ini disebabkan oleh kecepatan ulir pemeras yang cukup rendah yakni sebesar $33 \mathrm{rpm}$.

Rancangan komponen pemeras yang dirancang dengan sistem pemadatan diujung komponen menyebabkan ampas kelapa yang keluar dalam jumlah yang sedikit. Hal ini menyebabkan waktu proses pemerasan semakin panjang. Waktu yang dibutuhkan untuk melakukan pemerasasn 1000 gram kelapa parut selama 12,01 menit.

\section{g. Rendemen Santan}

Berdasarkan persamaan tiga (3) rendemen santan yang diperoleh dari proses pemerasan sebesar $22,17 \%$. Proses ini dilakukan dengan sekali pemerasan. Kondisi ampas hasil pemerasan masih dalam keadaan basah sehingga dilakukan ulangan pemerasan dengan dua (2) kali pemerasan dan tiga (3) kali pemerasan. Fenomena hasil pemerasan dengan perlakuan tersebut ditunjukkan pada grafik berikut.

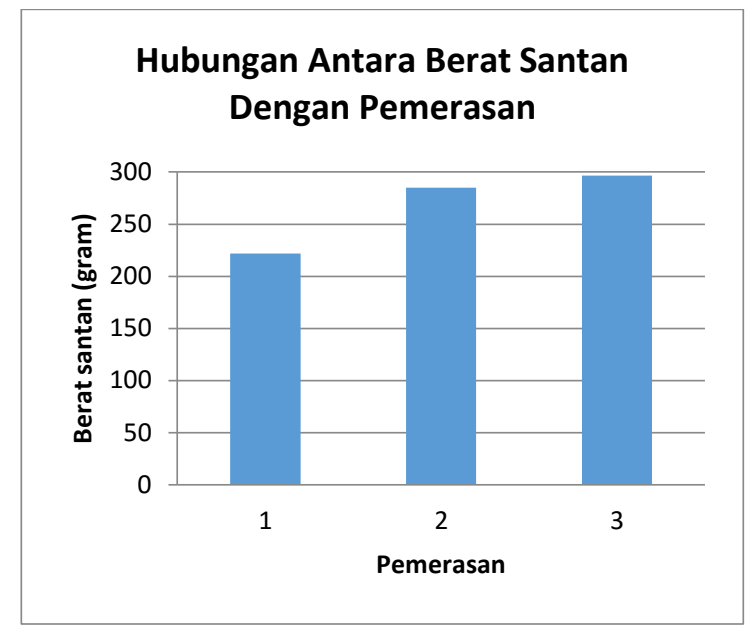

(a)

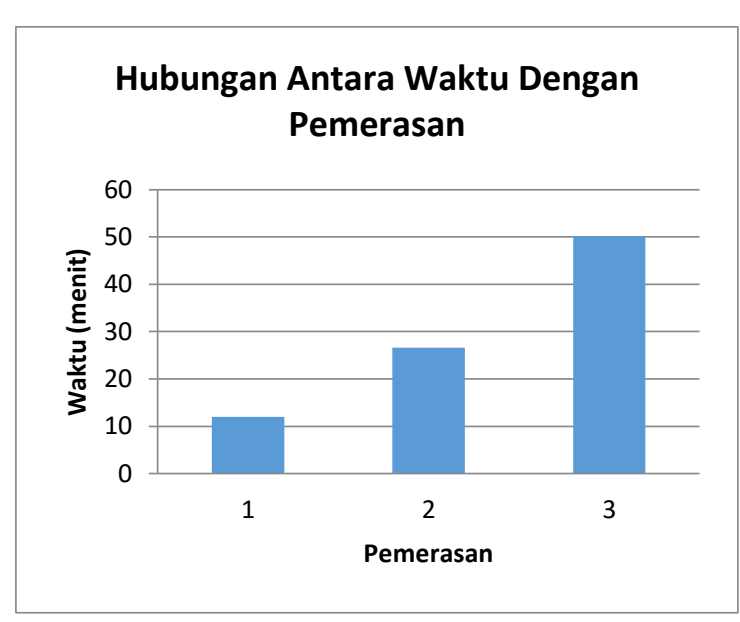

(b) 


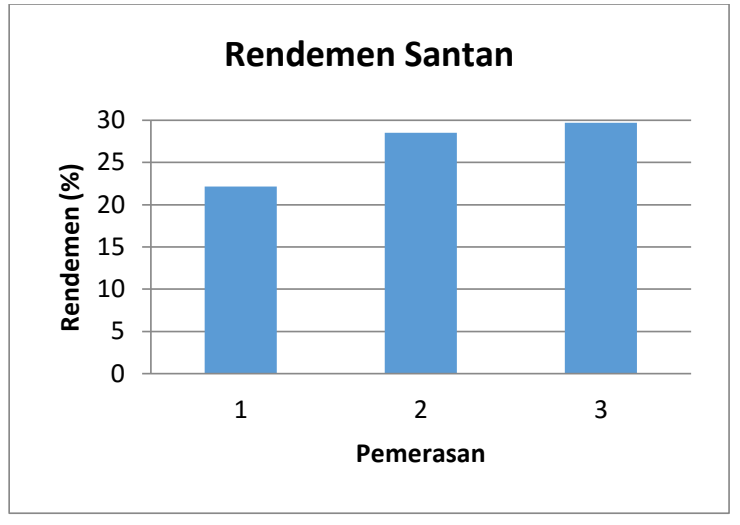

(c)

Gambar 2 Fenomena pemerasan santan dengan satu kali pemerasan, dua kali pemerasan dan tiga kali pemerasan.

Hubungan antara berat santan yang dihasilkan dengan Pemerasan seperti ditunjukkan gambar 2(a) menunjukkan bahwa peningkatan berat santan sebesar 63,33 gram pada pemerasan kedua dengan sampel yang sama. Penambahan berat santan pada pemerasan ketiga hanya sebesar 11,67 gram.

Hasil pemerasan dengan dua kali pemeran dan tiga kali pemerasan peningkatan waktu proses yang signifikan. Hal ini ditunjukkan pada gambar 2(b) dimana peningkatan waktu proses meningkat $50 \%$ pada proses dua kali pemerasan. Nilai yang sama juga terjadi dari dua kali pemerasan ke tiga kali pemerasan.

Rendemen hasil pemerasan (santan) pada gambar 2(c) menunjukkan bahwa peningkatan rendemen tidak signifikan. Total peningkatan rendeman hanya meningkat sebesar $7 \%$ dari rendemen dengan satu kali pemerasan namun terjadi dua kali peningkatan waktu proses.

\section{KESIMPULAN DAN SARAN}

\section{Kesimpulan}

Berdasarkan hasil penelitan menunjukkan :

1. Mesin pemarut dan pemeras santan kelapa mampu berkerja baik secara fungsional dan struktural

2. Kapasitas pemarutan sebesar $25,52 \mathrm{~kg} / \mathrm{jam}$ dan kapasitas pemerasan sebesar $5 \mathrm{~kg} / \mathrm{jam}$

3. Rendemen santan sebesar $22,17 \%$ dengan satu kali pemerasan dan meningkat sebesar $7 \%$ dengan dua dan tiga kali pemerasan

\section{Saran}

perlu penelitian lebih lanjut pada komponen saluran pengeluaran parutan kelapa yang sesuai dengan sudut curah (angle of repose) parutan kelapa sehingga parutan kelapa langsung mengalir ke komponen pemerasan. Analisa lebih lanjut juga diperlukan dilakukan dalam perancangan komponen pemeras sehingga hasil pemeras lebih maksimal.

\section{UCAPAN TERIMA KASIH}

Ucapan terima kasih disampaikan kepada Yayasan Pengembangan Sumber Daya Manusia (YPPSDM) Gorontalo dan Direktur Politeknik Gorontalo yang telah mendanai penelitian ini dalam hibah dana penelitian internal Politeknik Gorontalo 2018

\section{DAFTAR PUSTAKA}

Alifauzi AS, Rofarsyam. 2005. Mesin Pemeras Kelapa Parut Menjadi Santan Sistem Ulir Tekan Penggerak Motor Listrik 1 HP. Teknoin, Vol. 10, No. 4, Desember 2005, 249-256

Belo KI, Balogun AL, Limidi BO. 2014. Design, Fabrication and Testing Coconut Milking Machine. Journal Of Reseacrh in Pure and Applied Sciences Volume 3 Number 1 June 2014

Lestari D, Susilo B, Yulianingsih R. 2014. Rancangan Bangun Mesin Pemarut dan Pemeras Santan Kelapa Portable Model Kontinyu. Jurnal Keteknikan Pertanian Tropis dan Biosistem. Vol. 2 No 2, Juni 2014, 117-123

Mizera C, Hrabe. P, Herak D. 2017. Mechanical Characterization of Whole Coconut Shell. 58th ICMD 6-8 September 2017, Prageu, Czech Republic.

Tonpe KK, Sakhare VP, Sakhale CN. 2014. Design $\&$ Performance of Coconut De-Shelling Machine. Journal of Engineering Research and Applications ISSN : 2248-9622, Vol 4, Issue 7 (Version 3), July 2014, pp.39-44 